\title{
Purification and Mode of Action of Two Bacteriocins Produced by Serratia marcesens HY
}

\author{
By R. EICHENLAUB AND U. WINKLER \\ Lehrstuhl Biologie der Mikroorganismen, Ruhr-Universität, \\ $D_{463}$ Bochum, Germany
}

(Received 19 November 1973; revised 6 February 1974)

\begin{abstract}
SUM MAR Y
Serratia marcescens strain HY was found to produce marcescin B in addition to the production of marcescin $\mathrm{A}$ which was already known. The synthesis of both marcescins was inducible by mitomycin $\mathrm{C}$, but $\mathrm{A}$ was induced much less than $\mathrm{B}$. Both marcescins were isolated from the culture fluid of a mutant deficient in exocellular protease, and purified by ammonium sulphate precipitation, gelfiltration, and ion-exchange chromatography on hydroxylapatite and DEAEcellulose. Marcescin A has a molecular weight of $2 \times 10^{6}$, is resistant to trypsin, attacks some $S$. marcescens as well as Escherichia coli strains, and its mode of action resembles, in many respects, that of colicin $E_{2}$, i.e. it inhibits the synthesis of DNA, RNA and protein in sensitive cells and, furthermore, causes degradation of DNA; at high concentrations it also degrades RNA. Marcescin B, on the other hand, has a low molecular weight (43000), is sensitive to trypsin, does not act on $S$. marcescens strains, and its mode of action seems to be similar to that of colicin $E_{\text {I }}$, i.e. it inhibits the synthesis of DNA, RNA and protein in sensitive cells without DNA-degradation. Thus, several properties of the two marcescins produced by strain HY agree well with the (few) data already published on marcescins derived from other strains. The synthesis of marcescin B resembles that of marcescin A as regards the pleiotropic effect of $n u c^{s u}$ mutations.
\end{abstract}

\section{INTRODUCTION}

Bacteriocins are proteins synthesized by certain strains of bacteria and characterized primarily by their lethal action upon some other bacterial strains. Fuller \& Horton (I950) first purified a bacteriocin, marcescin, from Serratia marcescens (strain $82 \mathrm{~B}$ ). Later it was found that different strains of $S$. marcescens produce at least two different marcescins, either together or singly (Hamon \& Peron, I96I; Prinsloo, I966): marcescins of group A, active mainly against certain strains of $S$. marcescens and Escherichia coli, and resistant to treatment with trypsin, chloroform or heat; and marcescins of group B, not lethal to S. marcescens but lethal to some strains of $E$. coli or Aerobacter aerogenes, and inactivated by trypsin, chloroform or heat (Prinsloo, 1966).

Strain HY of $S$. marcescens has been used frequently for genetic and physiological studies of Serratia bacteria. Winkler \& Timmis (1973) found that strain HY produced marcescin A and that this ability could be strongly increased by a pleiotropic mutation which also decreased the stability of some prophages and enhanced the synthesis of several exocellular enzymes. This paper describes the purification and characterization of marcescin $A$ and of marcescin B which was also found to be produced by strain HY. Since the wild-type of strain 
HY synthesizes an exocellular protease (Winkler, I968), and marcescins of type B are generally sensitive to trypsin, a mutant of strain HY completely deficient in this protease was used throughout the work. Some of our results have been briefly presented by Eichenlaub \& Winkler (1972).

\section{METHODS}

Bacteria and phages. Serratia marcescens, strain HY (from Dr M. Bunting), and its mutants w83 I ( prt) completely deficient in exocellular protease (Winkler, unpublished), and w83I/3 ( prt Bac ${ }^{\text {s11 }}$, syn. W9I6), which produces more marcescin A and B than the wild type. Escherichia coli w3 10 (from Dr F. Jacob), resistant to streptomycin and sensitive to marcescin A and B, was used to obtain spontaneous mutants sensitive only to marcescin A (W3IIOA, syn. w872), or only to marcescin B (W3IIOB, syn. W87I)*. These mutants were used as indicators for the selective titration of the two marcescins. E. coli $\mathrm{Hfr} \mathrm{H} 3000$ (from Dr P. Starlinger) was used as plating indicator for phage MS2 (from Dr P. Fortnagel) and E. coli $\mathrm{KI} 2(\lambda)$ (from Dr W. Wackernagel) to test the prophage-inducing ability of marcescin A. Phage $\lambda$ as obtained from lysogenic KI 2 and phage T40 (from Dr H. Prell) were plated on indicator w3 I 10.

Media. Liquid cultures of all bacterial strains used were grown in yeast-peptone medium (YPM) containing $(\%, w / v): 0.5 \quad \mathrm{NH}_{4} \mathrm{Cl}, 0 . \mathrm{I}^{\mathrm{N}} \mathrm{NH}_{4} \mathrm{NO}_{3}, 0.2 \mathrm{Na}_{2} \mathrm{SO}_{4}, 0.3 \quad \mathrm{~K}_{2} \mathrm{HPO}_{4}, 0 . \mathrm{I}$ $\mathrm{KH}_{2} \mathrm{PO}_{4}, 0.0 \mathrm{I} \mathrm{MgSO}_{4} .7 \mathrm{H}_{2} \mathrm{O}, 3$ Bacto peptone, 0.5 Bacto yeast extract and 0.2 glucose. For plating bacteria or phages (except $\lambda$ ) nutrient agar ( $\mathrm{N}$ agar) was used containing $(\%, \mathrm{w} / \mathrm{v})$ : 0.8 Bacto nutrient broth, I.5 Bacto agar and $0.4 \mathrm{NaCl}$; N soft agar contained only $0.5 \%$ $(w / v)$ Bacto agar. For assay of marcescins, $N$ agar supplemented with streptomycin at a final concentration of $50 \mu \mathrm{g} / \mathrm{ml}$ was used. Neutral phosphate buffer contained $(\%, \mathrm{w} / \mathrm{v})$ : $0.7 \mathrm{Na}_{2} \mathrm{HPO}_{4} .2 \mathrm{H}_{2} \mathrm{O}, 0.3 \mathrm{KH}_{2} \mathrm{PO}_{4}, 0.4 \mathrm{NaCl}$ and $2 \times 10^{-3} \mathrm{M}-\mathrm{MgSO}_{4}$. Phage $\lambda$ was plated on tryptone-yeast extract (TY) agar containing $(\%, \mathrm{w} / \mathrm{v}): \mathbf{I} \cdot 0$ Bacto tryptone, 0.5 Bacto yeast extract, $0.5 \mathrm{NaCl}$ and $\mathrm{I} \cdot 5$ Bacto agar (or 0.5 in the corresponding soft agar).

Chemicals. Streptomycin and chloramphenicol were obtained from Farbwerke Hoechst AG, Frankfurt/Main, Germany, mitomycin $\mathrm{C}$ from Sigma, rifampicin from Ciba, nalidixic acid from Winthrop Laboratories, Newcastle-upon-Tyne, tritiated thymidine, uridine and leucine from Amersham Buchler, Braunschweig, Germany, Sephadex G-20o and Blue Dextran 2000 from Pharmacia, DEAE-cellulose DE-52 from Whatman, hydroxylapatite Bio-Gel HTP from Bio-Rad Laboratories, Corning controlled-pore glass CPG-I0-2000 from Corning Glass, Corning, New York, U.S.A., Carbowax $20 \mathrm{M}$ from Union Carbide and the collection of marker proteins MS-I for gel-filtration from Serva Feinbiochemica, Heidelberg, Germany; all other chemicals were obtained from E. Merck AG, Darmstadt, Germany.

Assay of Marcescin A and B (spot test). Marcescin A was always assayed on Escherichia coli $\mathrm{W}_{3}$ I IOA and marcescin B on $E$. coli w3 I IOB. N soft agar $(2.5 \mathrm{ml})$ was seeded with IO stationary phase cells of $E$. coli $\mathrm{W}_{3} \mathrm{I} I \mathrm{IOA}$ or $\mathrm{W}_{3} \mathrm{I} \mathrm{IOB}$, grown in N broth, and layered onto $20 \mathrm{ml}$ $\mathrm{N}$-streptomycin agar in a Petri dish. After drying for I 5 min at $37^{\circ} \mathrm{C}$, volumes (0.0 $\mathrm{ml}$ ) of serial dilutions of a given marcescin preparation were placed on the agar surface. After overnight incubation at $37^{\circ} \mathrm{C}$ the plate was scored. The number of 'arbitrary units' (a.u.) per $\mathrm{ml}$ of marcescin was defined as the reciprocal of the greatest dilution of a given marcescin preparation which still prevented macroscopic growth of the indicator bacteria. When necessary, the concentration of marcescin in a given preparation was expressed in "lethal

* The genetic symbols we propose for the resistance (or tolerance) to marcescin $\mathrm{A}$ or $\mathrm{B}$ are $m^{\mathrm{r}} \mathrm{a}^{\mathrm{r}}$ $(=\mathrm{W} 3 \mathrm{I} \mathrm{IOB})$ and $m a b^{\mathrm{r}}\left(=\mathrm{W}_{3} \mathrm{I} I O \mathrm{~A}\right)$ respectively. 
units' (1.u.), defined as the smallest quantity of bacteriocin required to kill an average sensitive bacterial cell. Marcescin contents in 1.u./cell were calculated from: survival ratios as described in Results.

Preparation of marcescins (crude extracts). Serratia marcescens w83I/3 were grown in 2.51 YPM at $30{ }^{\circ} \mathrm{C}$ with vigorous aeration. The growth was followed by microscopic counts of the cells. When the count had reached $5 \times 10^{8} / \mathrm{ml}$, mitomycin $\mathrm{C}$ was added (final concn $\mathrm{I} \mu \mathrm{g} / \mathrm{ml}$ ) and the culture incubated for a further $5 \mathrm{~h}$. Bacteria were removed by centrifuging for $20 \mathrm{~min}$ at $10000 \mathrm{~g}$ and glycerol (final concn $10 \%$ ) and solid ammonium sulphate (final concn $60 \%$ saturation) were added to the supernatant. The precipitate formed was collected by centrifuging ( $15 \mathrm{~min}$ at $23300 \mathrm{~g}$ ) and dissolved in a small volume of phosphate buffer containing $10 \%$ glycerol. This crude extract could be stored at $-10{ }^{\circ} \mathrm{C}$ for several weeks with little loss of activity.

Measurement of the synthesis of DNA, RNA and protein. Bacteria were grown in Io $\mathrm{ml}$ YPM in a water bath $\left(37^{\circ} \mathrm{C}\right)$ with shaking until a count of $2 \times 10^{8} / \mathrm{ml}$ was reached, and then diluted $\mathrm{I}: 4$ in fresh YPM. Tritium-labelled thymidine, uridine or leucine were added (final concn $0 . \mathrm{I} \mu \mathrm{Ci} / \mathrm{ml})$, and the cultures were reincubated. Samples $(0.5 \mathrm{ml})$ were withdrawn at intervals and added to $0.5 \mathrm{ml}$ ice-cold $10 \%$ trichloroacetic acid (TCA), mixed rapidly, and left in ice for $30 \mathrm{~min}$. The precipitates formed were collected on glass fibre filters (Whatman GF/C, $2 \cdot 1 \mathrm{~cm}$ diam), successively washed with $5 \mathrm{ml}$ cold $5 \%$ TCA and $5 \mathrm{ml}$ cold $\mathrm{I} \%$ acetic acid, and finally dried in glass tubes for $15 \mathrm{~min}$ at $100{ }^{\circ} \mathrm{C}$. After addition of $5 \mathrm{ml}$ scintillant $\left[0.5 \%(\mathrm{w} / \mathrm{v}) 2.5\right.$-diphenyloxazol (PPO) and $0.022 \%$ (w/v) 2, $2^{\prime}$-p-phenylen-bis-(4-methyl5 -phenyloxazol) (POPOP) in toluene] the tubes were counted in a Packard Tri-carb liquid scintillation counter, model 3320 .

Biochemical tests. Protein estimations were by the method of Lowry, Rosebrough, Farr \& Randall (195I); enzyme assays were according to Kunitz (1946) for nuclease, using DNA as substrate (final concn $0.05^{\prime \prime}{ }^{\prime}$ ), and according to Castanedo-Agullo ( 1956 ) for protease, using casein as substrate (final concn $0.5 \%$ ).

Chromatographic equipment. We used an LKB Ultrorac 7000 fraction collector, an LKB Uvicord 4700 u.v. recorder and an LKB Vario-perpex I 20000 pump.

\section{RESULTS}

\section{The induction and isolation of the two marcescins}

The existence of two different marcescins was first demonstrated by using mutants of indicator E. coli $\mathrm{w}_{3} \mathrm{II}$, which were resistant or tolerant to one marcescin or the other. Furthermore, u.v.-induced mutants $\left(b a c_{A}\right)$ of strain HY which were unable to produce marcescin A could still synthesize marcescin B, at least after induction by mitomycin C.

The amount of marcescin A and B synthesized spontaneously in YPM by the wild type of $S$. marcescens HY was very low. To increase the yield of the marcescins the following procedure was used: Strain W83I, which is a double mutant of strain HY and completely deficient in exocellular protease, was irradiated with u.v. light $\left(N / N_{0} \sim \mathrm{I} \%\right.$, where $N_{0}$ is the initial number of cells and $N$ the number which survived), and mutants ( $b a c^{\mathrm{su}}$ ) were isolated which spontaneously produced more marcescin A and B than w83I (for the method see Winkler \& Timmis, 1973). One of these mutants (w83 I/3) was grown in YPM in the presence of I $\mu \mathrm{g}$ mitomycin $\mathrm{C} / \mathrm{ml}$ and the marcescins were isolated from the culture supernatant after $5 \mathrm{~h}$ incubation (for details see Methods). The induction of the synthesis of marcescin B by mitomycin $\mathrm{C}$ and the ratio of bound to free marcescin $\mathrm{B}$ was very much dependent on the time of incubation (Fig. 1). Marcescin A activity in a.u./ml was much less than that of mar- 


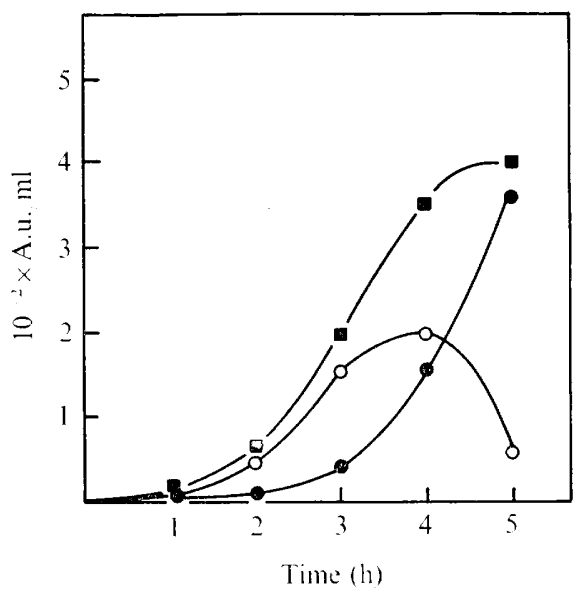

Fig. 1. Bound and free marcescin B in a culture of $S$. marcescens w831/3 grown in YPM in the presence of $\mathrm{I} \mu \mathrm{g}$ mitomycin $\mathrm{C} / \mathrm{ml}$. The antiobiotic was added at time $\mathrm{O}$ when the cell-titre was $5 \times 10^{8} / \mathrm{ml}$. Samples were taken and centrifuged for $10 \mathrm{~min}$ at $10000 \mathrm{~g}$. Free activity (O) was determined on the supernatant, and bound activity $(O)$ on the pellet, which was resuspended in the original volume of YPM, sonicated in a Branson cell disruptor ( $2 \mathrm{~min}$ at $90 \mathrm{~W}$ ) and centrifuged for 10 min at $43300 \mathrm{~g}$; then the supernatant was used. $\mathbf{\square}$, Total activity of marcescin B.

cescin B even after induction with mitomycin $\mathrm{C}$, but is not reported since the amount of marcescin $\mathrm{A}$ found in different experiments varied greatly.

Several mutants $\left(n u c^{s u}\right)$ of $S$. marcescens HY with increased production of exocellular nuclease, and known to be highly pleiotropic (Winkler, 1968; Winkler \& Timmis, 1973), also showed an increased spontaneous production of marcescin B, indicating some common feature in the regulation of the synthesis of nuclease and marcescin $\mathrm{B}$. The stimulating effect of $n u c^{\mathrm{su}}$ mutations on the synthesis of marcescin A has been described (Winkler \& Timmis, 1973).

\section{Chromatographic purification}

The marcescins were purified by gel-filtration followed by cation and anion exchange chromatography (Table I). All buffers used for washings and elutions contained $10 \%$ glycerol to protect the marcescins from inactivation.

The crude extract containing both marcescins was first applied to a Sephadex G-200 column and eluted with 0.0 I M-potassium phosphate buffer, $\mathrm{pH} 6.5$. Marcescins $\mathrm{A}$ and $\mathrm{B}$ appear near the void volume, indicating a high molecular weight (Fig. 2). For further use only fractions 17 to 2 I were taken (purification approx. $\times 60$ ). The next stage involved cation exchange chromatography on hydroxylapatite using three successive gradients with increasing concentrations of potassium phosphate (Fig. 3). The peak fraction of marcescin A appeared at an ionic strength of $0.15 \mathrm{M}$-potassium phosphate and that of marcescin $\mathrm{B}$ at $0.5 \mathrm{M}$. The pooled peak fractions containing marcescin $\mathrm{A}$ or $\mathrm{B}$, respectively, were each dialysed overnight against a solution of $0.02 \mathrm{M}-\mathrm{Na}_{2} \mathrm{HPO}_{4}$, adjusted to $\mathrm{pH} 7.5$ with $\mathrm{H}_{3} \mathrm{PO}_{4}$ and then chromatographed separately on DEAE-cellulose using a gradient of 0 to $0.5 \mathrm{M}-$ $\mathrm{NaCl}$. Marcescin A was mainly eluted at $0.25 \mathrm{M}-\mathrm{NaCl}$ and marcescin $\mathrm{B}$ at $0.11 \mathrm{M}-\mathrm{NaCl}$ (Fig. 4).

Fractions No. 65 to 72 containing marcescin A were pooled and showed a specific activity of 8333 a.u./mg of protein (purification approx. $\times 500$ ). The pooled fractions No. 36 to 42 

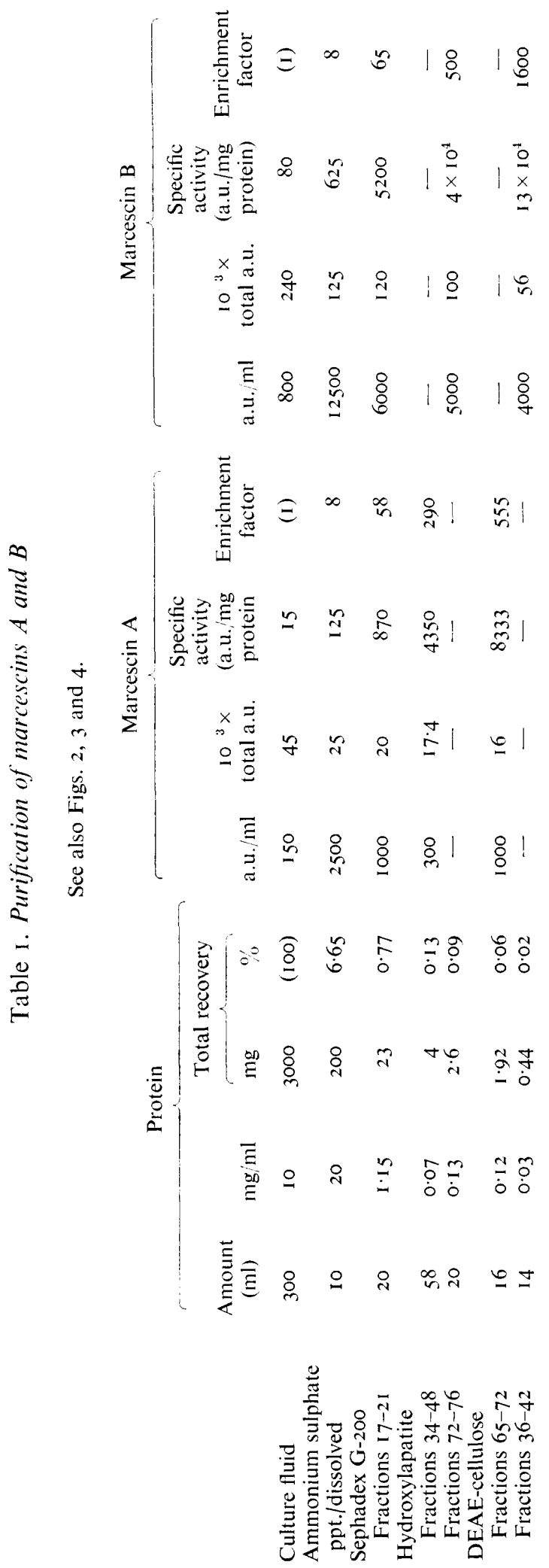


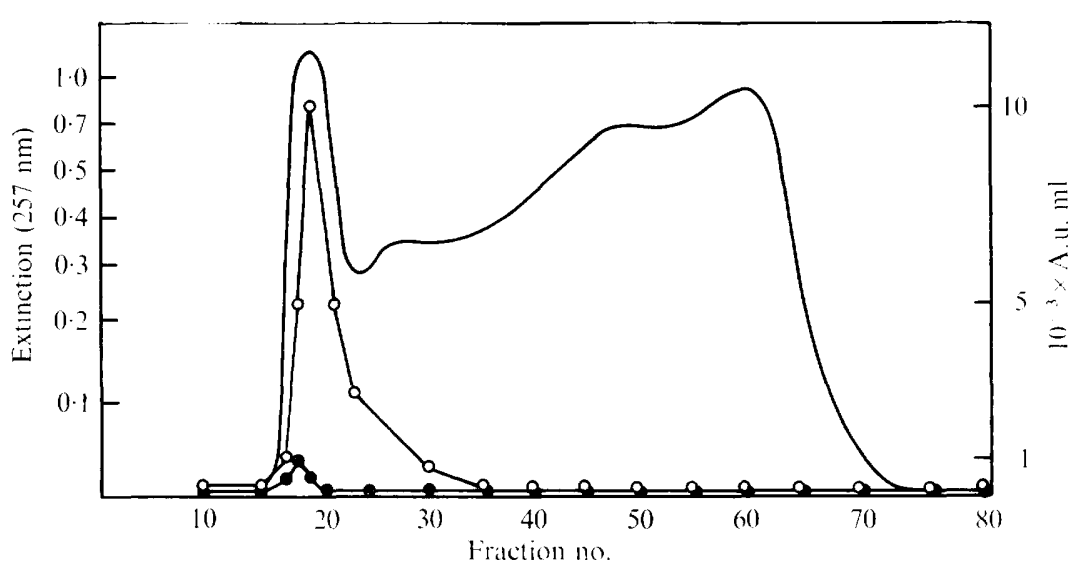

Fig. 2. Gel-filtration (Sephadex G-200) of the crude extract containing both marcescins. The column $(2.5 \times 37 \mathrm{~cm})$ was loaded with $200 \mathrm{mg}$ protein and eluted with $0.10 \mathrm{M}$-potassium phosphate buffer, $\mathrm{pH} 6 \cdot 5$. Fractions $(4 \mathrm{ml})$ were collected. The void volume was determined with Blue Dextran 2000. The u.v. absorption and concentration of the marcescins were measured as described in Methods.

-, Marcescin A; O, marcescin B; and continuous line, u.v. absorbance.

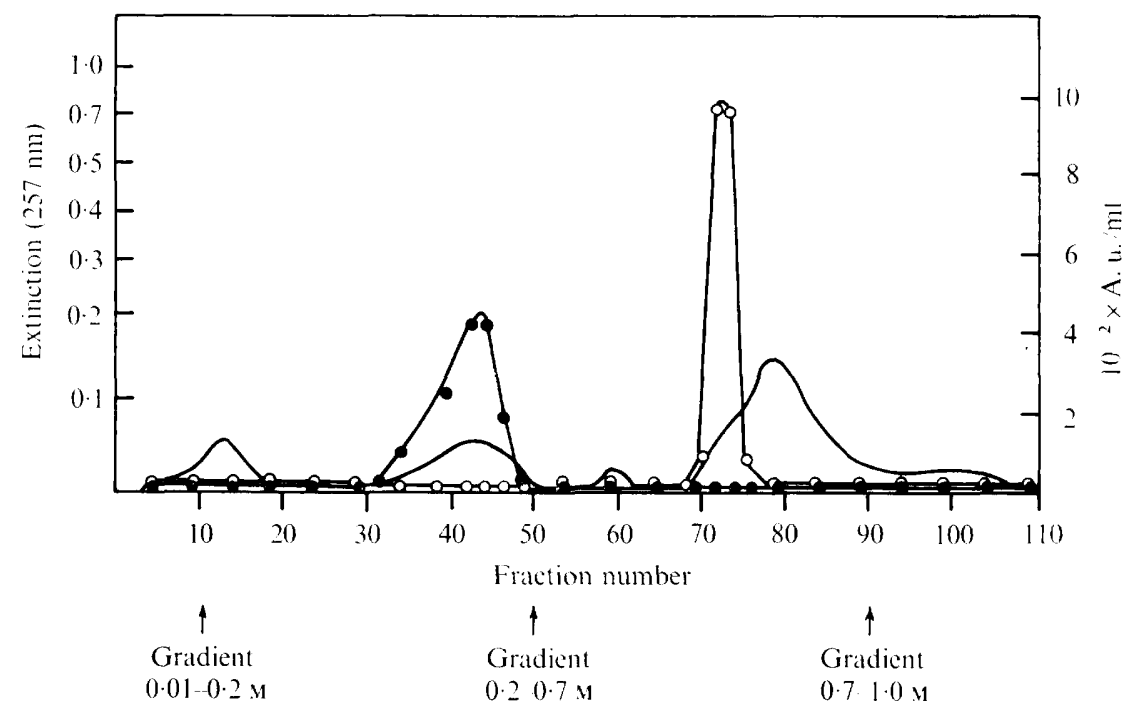

Fig. 3. Chromatography of partially purified marcescins on a column of hydroxylapatite. The pooled fractions Nos. 17 to 21 ( $23 \mathrm{mg}$ protein) from the gel-filtration were applied to a column $(2 \cdot 0 \times 22 \mathrm{~cm})$ and eluted with potassium phosphate buffer $(\mathrm{pH} 6 \cdot 5)$ of increasing concentration. Fractions $(4 \mathrm{ml})$ were collected. For further details and symbols see the legend to Fig. 2.

containing marcescin B had a specific activity of 127200 a.u. $/ \mathrm{mg}$ of protein (purification approx. $\times 1600)$.

\section{Molecular weights of marcescins $A$ and $B$}

Marcescin A was eluted from a column of Sephadex G-200 in the void volume (Fig. $5 b$ ), indicating a mol. wt greater than 800000 . Therefore the molecular sieve method with Corning controlled-pore glass (CPG-10-2000) was used to estimate the mol. wt of marcescin A which was found to be about $2 \times 10^{6}$ (Fig. $5 a$ ). This high mol. wt was supported by a 


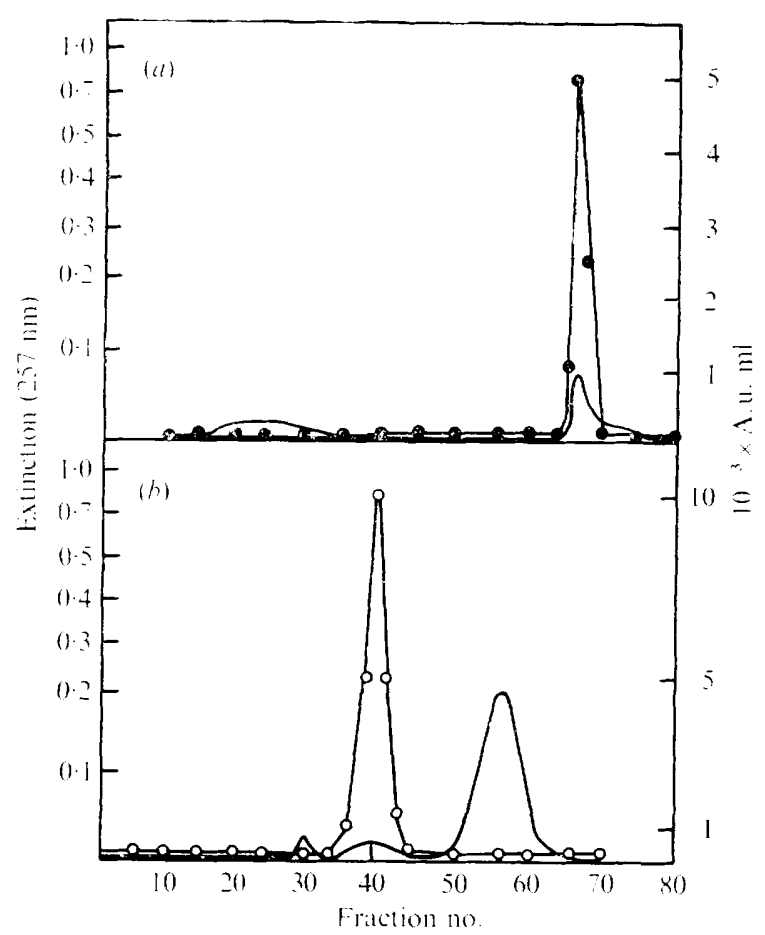

Fig. 4. Chromatography of partially purified marcescins on columns (each $2.0 \times 26.5 \mathrm{~cm}$ ) with DEAEcellulose using gradients of o to $0.5 \mathrm{M}-\mathrm{NaCl}$ in $0.02 \mathrm{M}$-sodium phosphate buffer, $\mathrm{pH} 7.5$, for the elution. (a) Marcescin A. The pooled fractions Nos. 34 to 48 ( $4 . \mathrm{I} \mathrm{mg}$ protein), derived from the chromatography on hydroxylapatite, were dialysed and then applied to the DEAE-cellulose column. (b) Marcescin B. The pooled fractions Nos. 72 to 76 (2.5 $\mathrm{mg}$ protein) were treated the same way. For further details and symbols see the legend to Fig. 2.

preliminary electron-microscopic examination of purified marcescin A showing filamentous structures resembling phage tails.

The mol. wt of marcescin B was found to be about 43000 by analytical gel-filtration with Sephadex G-200 and with O.I M-potassium phosphate buffer as eluant (Fig. $5 b$ ). With buffer of lower ionic strength marcescin $\mathrm{B}$ aggregates. When marcescin $\mathrm{B}$ was centrifuged in a sucrose gradient ( 5 to $20 \%$ ) in $0.02 \mathrm{M}$-tris- $\mathrm{HCl}$ buffer ( $\mathrm{pH} 7.3$ ), a $s_{20 \text {, w }}$ value of $3.5 \mathrm{~S}$ was found, corresponding to a mol. wt of about 80000 and perhaps indicating formation of dimers under these conditions. In this context it is relevant that marcescin B appeared near the void volume when it was purified by gel-filtration with Sephadex G-200 and 0.0 M-potassium phosphate buffer as eluant (Fig. 2), whilst killing of sensitive organisms by marcescin B showed a maximum at an ionic strength of $0 \cdot I \mathrm{M}$, which might also support the 'aggregate hypothesis'.

\section{Sensitivity to proteases and SDS-mercaptoethanol}

The purified marcescins ( $100 \mathrm{a} . \mathrm{u} . / \mathrm{ml}$ ) were incubated with trypsin or pronase (final concn $\mathrm{I} \mathrm{mg} / \mathrm{ml}$ ) for $30 \mathrm{~min}$ at $37^{\circ} \mathrm{C}$ and then assayed for their bactericidal activity. Marcescin B was completely inactivated, whereas marcescin A was not. The sensitivity of marcescin B to trypsin was also demonstrated by applying the enzyme to sensitive organisms immediately after adsorption of the bacteriocin, resulting in an increased proportion of surviving cells. 


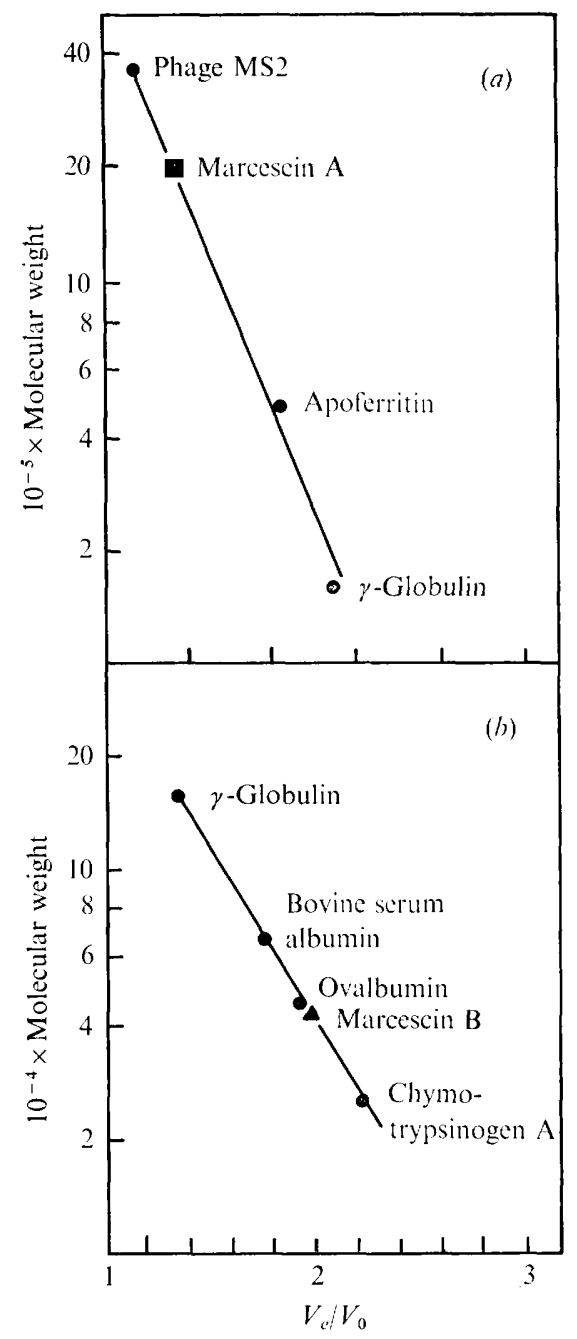

Fig. 5

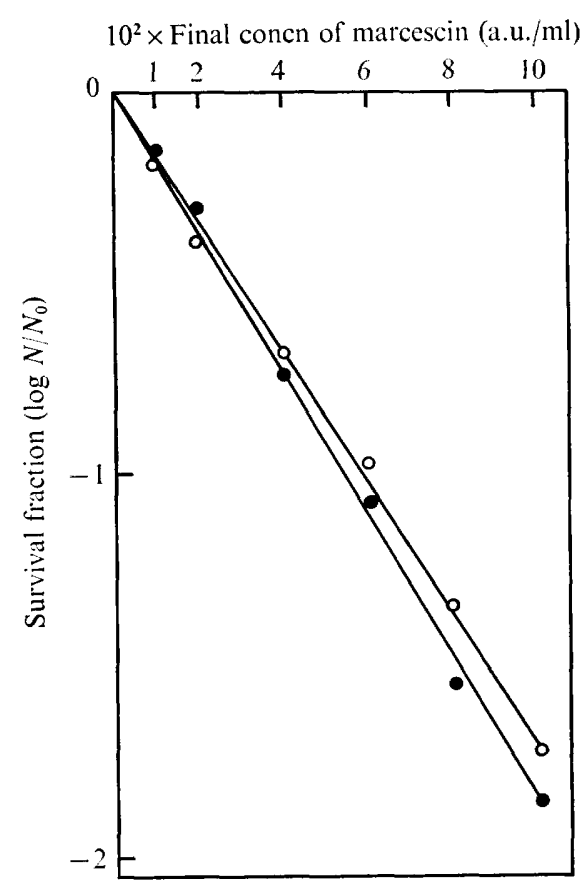

Fig. 6

Fig. 5. Determination of the molecular weight of purified marcescins by molecular sieve methods. Fractions ( $\mathrm{I} \mathrm{ml}$ ) were collected and analysed by spot tests (marcescins), plaque assays (phages) or spectrophotometry (marker proteins). (a) Marcescin A (250 a.u.) was applied to a column ( $1 \cdot 2 \times 39$ $\mathrm{cm}$ ) with Corning controlled-pore glass (CPG-10-2000 pretreated with Carbowax $20 \mathrm{M}$ ) and eluted with 0.1 M-potassium phosphate buffer, $\mathrm{pH} 6.5$, containing $10 \%$ glycerol. Together with marcescin A, two marker proteins (I mg of each), and the phage $\mathrm{T}_{4} \mathrm{O}\left(\mathrm{mol}\right.$. wt $\left.2.2 \times \mathrm{IO}^{8}\right)$ were used to determine the void volume. (b) Marcescin B (50 a.u.) was applied to a column $(\mathrm{I} \cdot 5 \times 84 \mathrm{~cm})$ with Sephadex G-200 and eluted with 0.1 M-potassium phosphate buffer, $\mathrm{pH} 6.5$, containing $10 \%$ glycerol. Together with marcescin B, four marker proteins (I mg of each), 250 a.u. marcescin A and $20 \mathrm{mg}$ Blue Dextran 2000 were eluted from the column, the latter in order to determine the void volume.

Fig. 6. Survival of $E$. coli W3 I I grown in YPM to a titre of $1.5 \times 10^{8} / \mathrm{ml}$ at different concentrations of marcescin A $(\bullet)$ and marcescin B (O). Cells $(0.9 \mathrm{ml})$ and $0.1 \mathrm{ml}$ solution of purified marcescin were mixed and incubated for $20 \mathrm{~min}$ at $37^{\circ} \mathrm{C}$. Then samples were diluted and plated on $\mathrm{N}$ agar. 
The bactericidal activity of both marcescins was completely inactivated $(>99 \cdot 9 \%)$ when incubated in a solution of $1 \%$ sodium dodecylsulphate and $\mathrm{I} \% \beta$-mercaptoethanol for $\mathrm{I} 4 \mathrm{~h}$ at $37^{\circ} \mathrm{C}$. Removal of the detergent and the reducing agent by dialysis did not restore the activity of the bacteriocins.

\section{Lethal effects on bacteria}

The survival of Escherichia coli W3I IO was studied as a function of the concentration of purified marcescins A and B. The survival curves obtained (Fig. 6) showed single-hit kinetics indicating that on average a single molecule of marcescin was sufficient to kill one bacterium. This agrees well with the observation that crude preparations of marcescin A inactivate S. marcescens W 243 by single-hit kinetics (Winkler \& Timmis, 1973). Microscopic and spectrophotometric examinations of $E$. coli treated with marcescin A or B $\left(N / N_{0}\right.$ about I \%) gave no indication of lysis within $4 \mathrm{~h}$ of adding the marcescin to the bacteria. From the survival curves, I a.u. corresponds to about $5.0 \times 10^{9} 1 . u$.

The inactivation of log cells of E. coli w3I IO by the purified marcescins was strongly $\mathrm{pH}$-dependent. When growing organisms were suspended in buffers with $\mathrm{pH}$ values ranging from $5^{\circ} \circ$ to 9.0 and then incubated with marcescin A or B (I a.u./ml) for 20 min at $37^{\circ} \mathrm{C}$, the lowest survival $\left(N / N_{0}\right.$ about $\left.\mathrm{IO}^{-4}\right)$ occurred between $\mathrm{pH} 7$ and 8 . At a $\mathrm{pH}$ of 5 or 6 the survival fraction was at least 100 times higher.

The range of activity of purified marcescins A and B was as follows. All of five different E. coli strains tested, including Bb, CR63 and Row, were sensitive to both marcescins. However, none of five different $S$. marcescens strains was sensitive to marcescin B, and only two (W243 and W38I) were sensitive to marcescin A. The growth of ten other bacterial strains (Shigella dispar $\mathrm{w}_{563}$, Bacillus subtilis $\mathrm{w} 770$, Salmonella typhimurium w264, Proteus vulgaris W45I, and of five strains of Staphylococcus aureus) was unaffected by both marcescins even using concentrations as high as 1000 a.u. $/ \mathrm{ml}$.

\section{Effects on the synthesis of macromolecules}

The mode of action of both marcescins on E. coli w3I Io was studied by measuring the synthesis of DNA, RNA and protein in the presence of small amounts (3 1.u./cell) of purified marcescins $\mathrm{A}$ and $\mathrm{B}$.

Marcescin A very rapidly blocked the synthesis of DNA, RNA and protein and furthermore caused degradation of DNA (Fig. 7). In this respect marcescin A resembles colicin E2 (see Nomura, 1967). When the concentration of marcescin A was raised from 3 to 8 1.u./cell the degradation of DNA was not changed but degradation of RNA occurred. In contrast to colicin E2 (Endo, Kamiya \& Ishizawa, I963) marcescin A was unable to induce prophage $\lambda$ when $E$. coli $\mathrm{KI} 2(\lambda)$ was treated with about $2 \cdot 5$ l.u./cell.

Marcescin B also caused immediate inhibition of the synthesis of DNA, RNA and protein, but neither DNA nor RNA was degraded, even at higher concentrations of the bacteriocin (Fig. 8). This suggests that marcescin B (similar to colicin EI; see Nomura, 1967) acts indirectly on these various biosyntheses, e.g. by depressing the supply of energy-rich compounds. This hypothesis was supported by our observation that motile bacteria, e.g. E. coli $\mathrm{Hfr} \mathrm{H} 3000$, when treated with marcescin B (3 l.u. $/ \mathrm{ml})$, lost their motility within $5 \mathrm{~min}$. Motility is a process requiring ATP. The consumption of oxygen by cells treated with marcescin B (5 l.u./cell), measured for $45 \mathrm{~min}$ at $37^{\circ} \mathrm{C}$ in a Warburg apparatus, was not significantly different from that of the control; one could therefore assume that marcescin B acts primarily by uncoupling oxidative phosphorylation. 


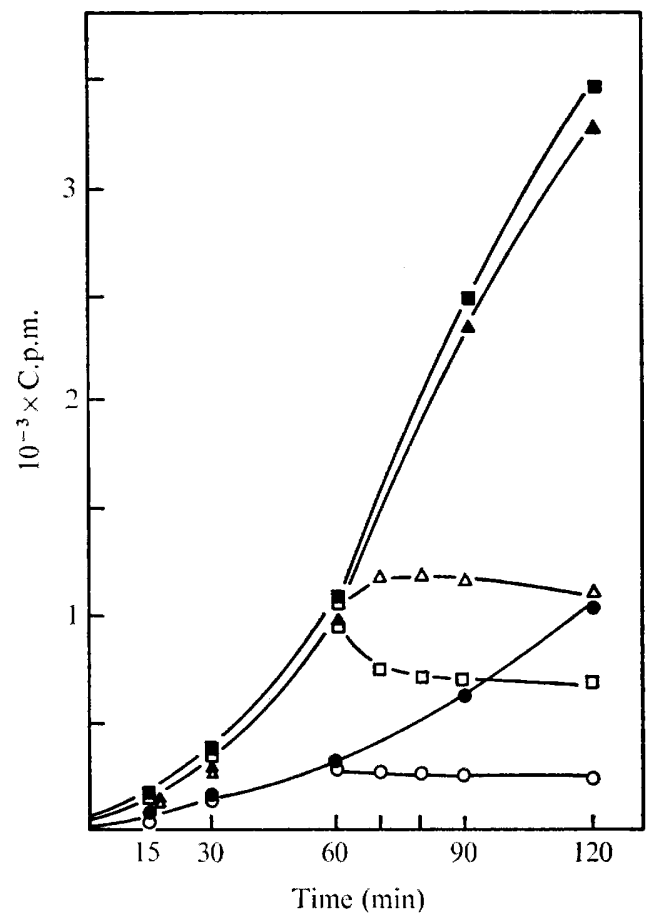

Fig. 7

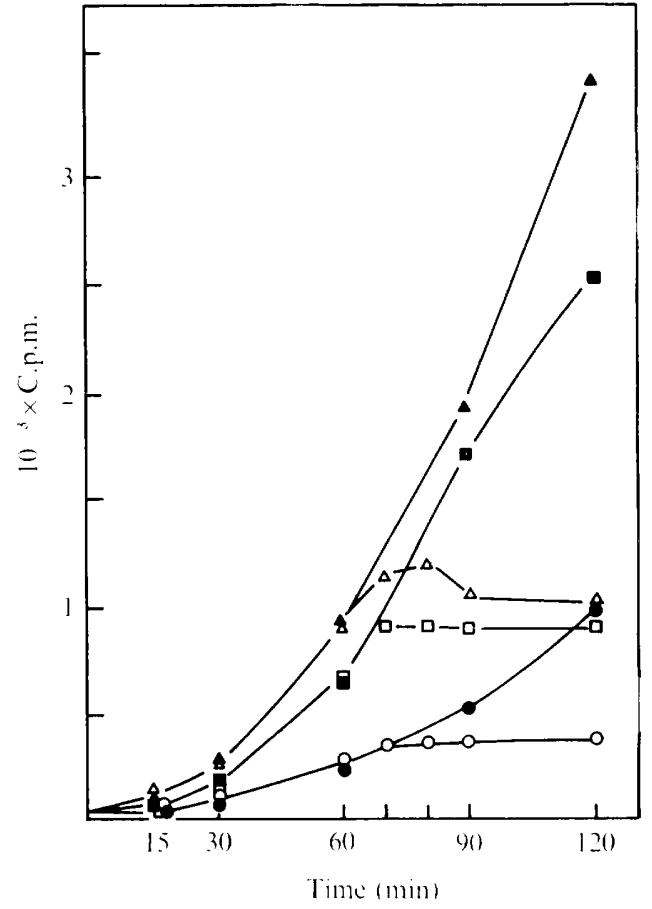

Fig. 8

Fig. 7. Effect of marcescin A on the synthesis of DNA, RNA and protein in E. coli w3IIOA. The incorporation of $\left[{ }^{3} \mathrm{H}\right]$ thymidine $(\boldsymbol{a}, \square),\left[{ }^{3} \mathrm{H}\right]$ uridine $(\boldsymbol{\Delta}, \triangle)$ and $\left[{ }^{3} \mathrm{H}\right]$ leucine $(O, \boldsymbol{O})$ in TCA-insoluble material of the cells was measured. Marcescin A (3.5 1.u./cell) was added to the culture at $60 \mathrm{~min}$ (open symbols). Control (solid symbols).

Fig. 8. Effect of marcescin B on the synthesis of DNA, RNA and protein in E. coli w3IIOB. Symbols as in Fig. 7. The synthesis of DNA and protein was measured in the presence of 6.5 l.u. marcescin B/cell and of RNA in the presence of 10 l.u./cell.

\section{DISCUSSION}

Eichenlaub \& Winkler (1972) reported that S. marcescens HY produces two different bacteriocins ('marcescins'), called A and B according to Prinsloo (1966)*. The present purification of the marcescins was difficult because they were produced by $S$. marcescens $\mathrm{HY}$ in small concentrations, even in the presence of mitomycin $\mathrm{C}$ which induces the synthesis of marcescin B.

Marcescin A. The molecular weight of purified marcescin A as estimated from molecule sieving experiments was about $2 \times 10^{6}$. A preliminary electron-microscopic examination of the same preparation (Eichenlaub, unpublished) showed that marcescin A has a shape similar to a phage tail, so that the molecular weight reported is probably a little high, since molecular weights estimated by gel-filtration or similar techniques are based on the belief that the macromolecule examined has a globular shape. Traub (1972) found that some marcescins were identical with phage tails, but this report was inconclusive since crude bacteriocin preparations were used which may have been contaminated if a defective lysogenic strain was used.

* By mistake, the nomenclature of the marcescins used in Eichenlaub \& Winkler (1972) was the reverse of the usual system employed by Prinsloo (1966). 
Timmis \& Winkler ( 1973 ) reported that marcescin A is coded by covalently-closed circular (plasmid) DNA with an $S_{20, w}$ value of about 54S. Since this $s_{20, w}$ value is close to that of component I-DNA of phage $\lambda$ (Kiger, Young \& Sinsheimer, 1968) one might consider marcescin A to be a protein coded by the DNA of a temperate phage which was defective as a result of one or more nonsense-mutations.

No death or lysis of cells has so far been observed when exocellular marcescin A is produced. Either the fraction of cells in a culture which performs 'lethal synthesis' of marcescin A is very low, or the bacteria survive when releasing marcescin A into the medium. The latter is not unlikely because cells of another member of the Enterobacteria, E. coli, may liberate the filamentous phage $\mathrm{fd}$ without destruction of the host (Hoffmann-Berling, Dürwald \& Beulke, 1963). The question, 'lethal synthesis or release?' can also be asked when one considers that the culture medium of $S$. marcescens HY contains a lipase of mol. wt above 800000 (Neumann, Thöner \& Winkler, I973).

In some respects the mode of action of marcescin A resembles that of colicin E2 (Nomura, I 967 ; Nose \& Mizuno, I968) and of T4 ghosts (Duckworth, I970), since all three proteins block the synthesis of DNA, RNA and proteins in sensitive cells. However, unlike marcescin A, $T_{4}$ ghosts are not able to induce the degradation of host-DNA (Swift \& Wiberg, 1973) and colicin E2 differs in its inducing effect on prophage $\lambda$. Although the synthesis of all macromolecules is blocked by marcescin A, colicin E2, and T4 ghosts, it does not necessarily follow that the molecular actions of these proteins have any steps in common.

Marcescin $B$. The marcescin B produced by $S$. marcescens HY seems to be almost identical to that already isolated from S. marcescens JF246 (Foulds, I97I, 1972): (i) The smallest molecular weights found were 64000 (strain JF246, polyacrylamide-gel electrophoresis) and 43000 (strain HY, gel filtration). Under our conditions, marcescin B stayed fully active. However, sodium dodecylsulphate, as used for the gel electrophoresis by Foulds, destroyed it completely. (ii) Marcescin B from both strains formed aggregates with molecular weights of up to $10^{6}$. Their formation seemed to depend on the ion concentration. (iii) Marcescin $\mathrm{B}$ from both strains blocked the synthesis of macromolecules in sensitive cells without degrading host-DNA as described for colicin EI and K (see Nomura, 1967). According to Foulds (I972) and Duckworth (1970), this general blockage does not seem to result from the depression of the intracellular ATP-pool by marcescin B or T4 ghost. Therefore uncoupling of oxidative phosphorylation after marcescin B treatment of sensitive cells is probably not the cause of the immediate inhibition of macromolecular synthesis.

Various cellular processes affected by bacteriocins, e.g. DNA synthesis, oxidative phosphorylation, and active transport, are located at or near the cell-membrane. Since little is known about the primary molecular events following bacteriocin adsorption to the bacterial membrane, further study is necessary.

Appendix. When the experiments presented in this paper were almost completed it was reported that $S$. marcescens $\mathrm{HY}$ is lysogenic for the phages $\psi$ and y (Steiger, 1973). Dr $\mathrm{H}$. Steiger, Frankfurt, Germany, supplied us with a non-lysogenic derivative (W I I I 3). Using this strain as indicator some $\mathrm{y}$ and $y^{\prime}$ phages could be detected even in our most purified preparations of marcescin A and B. However, experiments of Winkler \& Timmis (1973) and Eichenlaub (unpublished) showed conclusively that neither marcescin A nor B represent substructures of either of the two phages and furthermore that none of the properties attributed in this paper to marcescin $\mathrm{A}$ or $\mathrm{B}$ are artefacts due to contamination by phage.

The technical assistance of Mrs Karin Noll and the help of many colleagues who supplied us with bacterial strains or phage stocks is gratefully acknowledged. Some of the results were 
submitted by R. E. in partial fulfilment of the requirements for a Ph.D. at the Abteilung für Biologie, Ruhr-Universität, Bochum, Germany.

\section{REFERENCES}

Castanedo-Agullo, M. (1956). Studies on the biosynthesis of extracellular protease by bacteria. I. $S$. marcescens in synthetic and gelatin media. Journal of General Physiology 39, 369-375.

DUCKWORTH, D. H. (1970). Biological activity of bacteriophage ghosts and 'take-over' of host functions by bacteriophage. Bacteriological Reviews 34, 344-363.

EICHENlaub, R. \& WinkleR, U. (1972). Die Marcescine von Serratia marcescens, ihre Eigenschaften und Wirkungsweise. Hoppe-Seyler's Zeitschrift für physiologische Chemie 353, 702.

Endo, H., KamiYA, T. \& Ishizawa, M. (1963). $\lambda$-Phage induction by colicin E2. Biochemical and Biophysical Research Communications 6, 477-482.

FouLDS, J. D. (I97I). Mode of action of a bacteriocin from Serratia marcescens. Journal of Bacteriology 107 , 833-839.

Foulds, J. D. (1972). Purification and partial characterization of a bacteriocin from Serratia marcescens. Journal of Bacteriology 110, I00 I-I009.

Fuller, A. T. \& HoRTON, J. M. (I950). Marcescin, an antibiotic substance from Serratia marcescens. Journal of General Microbiology 4, 417-433.

Hamon, Y. \& Peron, Y. (I961). Étude de la propriété bacteriocinogène dans le genre Serratia. Annales de l'Institute Pasteur roo, 818-82I.

Hoffmann-Berling, H., Dürwald, H. \& Beulke, J. (1963). Ein fädiger DNS-Phage (fd) und ein sphärischer RNS-Phage (fr) wirtsspezifisch für männliche Stämme von E. coli. Zeitschrift für Naturforschung $\mathbf{1 8 b}$, 893-898.

Kiger, I. A., Jun., Young, E. T. \& Sinsheimer, R. L. (1968). Purification and properties of intracellular lambda DNA rings. Journal of Molecular Biology 33, 395-413.

KUNITZ, M. (1946). A spectrophotometric method for the measurement of ribonuclease activity. Journal of Biological Chemistry 164, 563.

Lowry, O. H., Rosebrough, N. J., Farr, A. L. \& Randall, R. J. (195I). Protein measurement with the Folin phenol reagent. Journal of Biological Chemistry 193, 265-275.

Neumann, S., Thöner, M. \& WinkleR, U. (1973). Zur Genetischen und Biochemischen Charakterisierung der Extrazellulären Lipase- und Protease-Aktivität bei Serratia marcescens. Abstract 34. Essen: Tagung der Deutschen Gesellschaft für Hygiene und Mikrobiologie.

Nomura, M. (1967). Colicins and related bacteriocins. Annual Reviews of Microbiology 21, 257-284.

Nose, K. \& Mizuno, D. (1968). Degradation of ribosomes in Escherichia coli cells treated with colicin E2. Journal of Biochemistry 64, $\mathrm{I}-6$.

PRINSLOO, H. E. (1966). Bacteriocins and phages produced by Serratia marcescens. Journal of General Microbiology 45, 205-2I 2 .

STEIGER, H. (I973). Genetic studies with two prophages naturally resident in Serratia marcescens HY. Molecular and General Genetics 122, 345-352.

Swift, R. L. \& Wiberg, J. S. (I 973). Bacteriophage T4 inhibits colicin E2-induced degradation of Escherichia coli desoxyribonucleic acid. Journal of Virology II, 386-398.

Timmis, K. \& WinkLER, U. (I973). Gene dosage studies with pleiotropic mutants of Serratia marcescens superactive in the synthesis of marcescin A and certain other exocellular proteins. Molecular and General Genetics 124, 207-21 7 .

TraUb, W. H. (1972). Studies on group A bacteriocines of Serratia marcescens: preliminary characterization of two subgroups of bacteriocins. Zentralblatt für Bakteriologie, Parasitenkunde, Infektionskrankheiten und Hygiene (Abteilung I) 222, 232-244.

WINKLER, U. (I968). Mutants of Serratia marcescens defective or superactive in the release of a nuclease. In Molecular Genetics, pp. I 87-20I. Edited by H. G. Wittmann and H. Schuster. Berlin, Heidelberg, New York: Springer Verlag.

WINKLER, U. \& TIMmIS, K. (1973). Pleiotropic mutations in Serratia marcescens which increase the synthesis of certain exocellular proteins and the rate of spontaneous prophage induction. Molecular and General Genetics 124, 197-206. 